\title{
From religious transcendence to political utopia: the legacy of Richard Turner for Post-Apartheid political thought
}

\section{Laurence Piper}

Abstract: In recent times South African politics has come to exhibit features typical of many post-colonial contexts, not least the rise of acrimonious and confrontational politics based around personalities and forms of populism. In such contexts rational dialogue and democratic deliberation become increasingly difficult to get going and to sustain. Drawing on Richard Turner's The Eye of the Needle, first published some forty years ago, the paper examines the role religion, and religious organisations, could play in returning such acrimonious - $(\mathrm{J}:)^{-}$public debate to more democratic and visionary grounds. The key point is that religion offers a form of transcendence from the divisive and bitter particularities that animate contemporary political conflicts. It does this through the spiritual affirmation of our shared human worth due to the love of God(s). From this recognition, achieved through spiritual appeals, the conditions for more rational and democratic debate can be retrieved. In addition, religious transcendence redeems the value of utopian thinking, and thus could help re-orientate public debate from a politics of blame for past wrongs to a politics of imagining of future rights.

Keywords: common human worth: faith-based organisations: post-colonial, post-apartheid politics; religious transcendence; Richard Turner.

\section{Introduction}

It seems that Tutu pulled the Commission out of its agonies by resorting to means beyond the limitations of discursive logic. I wondered to what extent his management style resided in his ability to recognise those precise moments at which a resort to spirituality provides a unifying transcendence that allows him to assume, and remain in, authority.

Njabulo Ndebele (2007:78).

Faith-based organisations have tremendous but underused potential as sites for developing active democratic citizenship in South Africa. This is due both to the extent of religious identification and organisation in the country, and the normative commitment of the major religions in South Africa to a political theology of democracy and development distinct from partisan politics. Further, these political theologies constitute significant normative alternatives to the tremendous legitimacy enjoyed by ruling elites (for a larger discussion of the above see Piper 2009). Substantive development of these political theologies may still be required, particularly as regards the appropriate limit to the relationship between religion and politics. Further, while a number of progressive theologies already exist in South Africa, and were loudly proclaimed during the struggle 
era, their voices have quietened of late, and more conservative religious projects are leading public debate. The challenge of developing and amplifying these progressive political theologies thus remains.

However important as these tasks are, they are not my concern in this piece. Rather than examining the significance that 'politics has for religion' in the usual fashion of anti-colonial political thought, I want to engage more closely with the significance of 'religion for politics'. The hope is to begin to take seriously the centrality of the spiritual to, and for, the post-colonial condition, or in South Africa's case, the post-apartheid condition. In addition I want to begin to explore some implications of reversing Kwame Nkrumah's famous phrase, 'seek ye first the political kingdom', for normative and utopian political thought. Perhaps it is the case that in our context imagining a different political future is well inspired by seeking first the kingdom of god.

To this end I examine the significance of religion for political thought through the arguments of the late Richard Turner, Political Science academic and anti-apartheid activist, in his work The Eye of the Needle. Intended to convince a white Christian audience that sincere religious practice had definite social implications which included the rejection of Apartheid and the affirmation of a social order based on human love and recognition, Turner anticipates the relevance of religious thought to contemporary post-apartheid life. As Chapman (2008) notes, the post-colonial condition is one of racial division, cultural heterogeneity, sharp socio-economic inequality, disease and crime, fragile political institutions, and the ominous politics of personality. In South Africa's case one could add a national mood of heightened anxiety and foreboding at recent social and political developments, especially the rise of personality-based politics and populist politics that mobilise from common prejudices against, for example, sexual minorities and foreigners - a zeitgeist captured powerfully in the recent film District 9.

It is precisely in this uncertain and even ominous context that religion gains heightened significance for politics - and not only because of the extent of religious identification and organisation, and the commitment of many religions to democracy and development-but much more so because of the transformative potential of the spiritual. Central here is religion's special capacity to lift us out of the particular and the negative, and to imagine a future that is based on common human recognition and love, and to do this through a power other than rational and democratic debate. The point is not that religion replaces debate, but that religion can provide resources to transcend a refusal to engage rationally and democratically and thus can help to get debate going.

It is this power that Ndebele identifies in his account (quoted above) of Archbishop Desmond Tutu's leadership style role in the Truth and Reconciliation Commission (TRC), and which Rick Turner draws on in the Eye of the Needle. However, where Ndebele sees transcendence as affirming authority, Turner sees transcendence as affirming key values, and then builds a normative and utopian political vision from these. In drawing out and amplifying Turner's insights, this paper will demonstrate how spiritual transcendence is 
one important way of breaking the shackles of the post-apartheid political anxiety, and also affirming of normatively imagining 'a better life for all'.

The paper begins by outlining and engaging Turner's key arguments in the Eye of the Needle in the following two sections, before making a case in the final section for their relevance to a post- apartheid politics of hope which includes an important role for faithbased organisations.

\section{Utopia, Transcendence and Love}

Published in 1972, The Eye of the Needle: An Essay on Participatory Democracy was written in response to the South African Council of Churches (SACC) Special Programme for Christian Action in Society (Spro-cas) / Study Project on Christianity in Apartheid Society (Spro- cas). ${ }^{1}$ Notably, Turner was writing at a time in South African history when Apartheid, the central project of the ruling National Party, was at its most triumphant. White power, maintained through a monopoly of the ballot and the security forces, was at its peak following the military crushing of organised resistance inside the country in the early 1960s, and the promulgation of many repressive laws on free speech, association and political activity.

Under the stewardship of the most ideological of apartheid leaders, Hendrik Verwoerd, the racist order was painted over with the ethnic veneer of 'grand apartheid', where black African South Africans were designated as members of ethnic groups rather than races, stripped of their citizenship, and assigned to rural areas which were portrayed as 'national homelands' to become 'independent' in time. Opportunistically embracing the language of decolonisation in Africa, grand apartheid was really an attempt to shore up the migrant labour system and thus secure the supply of cheap labour for the mines and industry, and to legitimise apartheid exclusion to the international community. No real powers were ever transferred to the homelands.

The 1960s also saw the South African economy reach new heights with the mining-led boom, lifting white prosperity to unprecedented heights. Indeed, the embrace of racially-based capitalism in the context of the cold war was useful in securing western support for the South African regime, and to delegitimize anti-apartheid resistance as some form of communism. Further, many of the churches in South Africa reinforced and even openly supported the apartheid order, with the leading protestant Afrikaner church, the Nationale Gereformeerde Kerk (NGK) described as the 'National Party at prayer'.

There were some sources of resistance however, not least the mass of the people who experienced the brutality of Apartheid first-hand. Another remaining organisational source of anti-apartheid discourse was the liberal South African Council of Churches (SACC), comprising many black churches, which sought to challenge the theological justifications of Apartheid. This was the point of the SACC's Special Programme for Christian Action in Society (Spro-cas), in which Turner participated.

Turner himself was a political theorist at the (then) whites-only University of Natal, heavily influenced by the writings of Marx, Rousseau and Sartre, amongst others, and an 
activist in the burgeoning labour movement in the city of Durban. Indeed. According to the American political theorist Ronald Aronson, Rick Turner's Eye of the Needle was the single most eloquent and most lucid account of the views that came to characterise the 1969 moment (De Kadt 2010). Thus both intellectually and politically, Turner was widely recognised as a leading anti-apartheid figure, as confirmed by his banning by the apartheid state in 1973 for five years, and subsequent assassination, again by the apartheid state, in 1978.

Coming from this pedigree, it is probably not surprising that Turner, was frustrated by the limited focus of the Sprocas' Political and Economic Commissions on just analysing contemporary South African life, rather than imagining the future. Thus the Eye of the Needle represents an attempt at normative and utopian political theory, but one built on religious foundations (pp. 3-4). Hence Turner argues:

Christianity does not just condemn racism. It constitutes a challenge to all accepted values, an invitation to continuous self-examination, to a continuous attempt at transcendence... We may find that Christianity is incompatible not only with our racism, but also with many of the other norms regulating our behaviour, and that in order to live in a Christian way we will need radically to restructure our society.

Normative thought often involves what Turner calls 'utopian thinking' (p. 3). Typically utopian thinking, or normative imagining, offers a model or blueprint of the ideal society which we may never realise but ought to strive towards. Turner argues that in addition to identifying our social goal, utopian thinking helps us understand better what we can change and we cannot, but also empowers us to understand how and why our society works as it does (p. 5). In short, there are real empirical benefits to this kind of normative exercise. Perhaps more importantly for this paper, Turner argues that what is required to think normatively though, is 'shifting oneself into a theoretical attitude' and to 'grasp the present as history' (p. 7), by which he means something like being open to critical reflection on what is particular and contingent in our experience versus that which is universal and essential. As we shall see, Turner believes that religious experience can contribute to developing precisely this attitude: it can help us imagine the future in a reflective way.

In making this case, Turner criticises the notion of human nature as an explanatory concept on both empirical and theoretical grounds. He holds that the idea of a fixed and specific human nature is an empirically unsupported idea-indeed he sees the content of human nature as always reflecting dominant social norms. Theoretically, he sees the idea of a human essence that predicts behaviour as challenged by the reality of free will (p. 9). Further, the social conformity that exists in spite of free choice is explained in terms of socialisation, and the point of socialisation is 'to make a particular social structure and a particular human need seem to be natural, and to hide the fact that it is not natural and should be challenged' (p. 11). This analysis also forms the basis of his critique of the notion of 'common-sense' as 'normalised' convention. Notably, in poetic inversion, he finishes 
The Eye of the Needle by arguing for the impracticality of the apartheid system and the alleged 'realism' that underpins it.

Having criticised the explanatory power of the idea of a fixed 'human nature', and pointed to the 'naturalising' effect of socialisation on the human capacity for free choice, Turner identifies two kinds of moral response to social relationships. The first accepts the dominant model of society and 'tries to rationalise it, to smooth the edges'. Turner calls this 'internal' morality. For example, 'pay your debts, give to the poor, don't tell lies... In a slave society, feed your slaves properly, don't sell your children until they are eight years old. In wars, kill enemies with bullets, but not with poison gas' (p. 17). Arguing that internal morality makes life easier for people and so should not be 'sneered' at, he notes that it does not challenge the human model inherent in the system. Against this he defines 'external morality' as based on a transcendent morality - as going beyond the given and asking the fundamental question 'what is human life for, and what is the meaning of human life?' (p. 17).

Turner argues that Christianity embodies a transcendent morality rather than an internal morality. Indeed, he expands this to all religions arguing (ibid):

The essence of all religions lies in the concept of transcendence - that is, in the idea of something (whether it be a 'reality' or an 'ideal') which goes beyond the present, which goes beyond what people are doing in the world at this moment, and in the light of which the present is only of secondary importance. That is, religion challenges the commonsense tendency to be committed to the present, to see the world as we experience it now as the only possible form of reality.

Further, the challenge posed by religion occurs both on the level of a transcendent reality (God) and a transcendent ethic. He notes that the challenge posed by the idea of God is in revealing the partiality of our knowledge of ourselves, and the world. The challenge of the transcendental ethic is the practical attitude that flows from the realisation that our partial knowledge means our ways of behaving may be flawed, and we ought continually to question them (p. 18):

No great leader has said: 'Change your beliefs, but continue to act in the way you have always acted'. Each leader has attacked both old social forms and old religious forms. He has attacked old religious forms which have precisely lost their transcendence and become mere repetitive rituals. He has attacked social forms which have become both unquestioned and hence mechanical and non-human, and unjust, thereby dehumanising.

Further, the social relevance of religion lies in the fact that it commands us to question accepted human models and the accepted social structure in which they are embodied (p. 19). Importantly he argues that Christianity is not an 'other-worldly' religion, and that 'the very doctrine of the incarnation of God in this world expresses the central importance of this world and of human history for Christianity' (p. 19). Citing examples from J udaism, Christianity and Islam, Turner argues that the history of religious decay and reform is the history of the gradual decline of transcendent beliefs and practices 'into the given', a decline whereby they become nothing more than a traditional way of life in which religion reduces to ritual and the transcendent ethic 'gets moulded into the very untrascendent social structure', and becomes an opiate to the people until a new reformer shatters the 
structure either by creating a new religion (Muhammed) or revitalising the old (Calvin) (p. 19).

There appears to be a tension here around the usage of 'religion': having argued that 'great' religion is transcendent, Turner also argues that 'ritualised' religion often endorses an oppressive status quo. In this regard it is notable that Turner points to the role of Christianity in justifying the ideology of white supremacy during the period of European colonisation, playing a 'vital supporting role' to the military (p. 25). Hence where religion in transcendent mode is liberatory and transforms social power, in routinised mode it usually conserves the social order. The real value of religion lies in the former, and the conservative role of religion, both spiritually and socially, lies in the latter. Although not explicitly drawn by Turner, the distinction between 'transcendent' and 'routinised' religion runs through The Eye of a Needle and is safely inferred from his argument. Importantly, it signals the distinction between the insights gained from the religious experience and the project of building a social order on these insights. As will be argued below, it is not Turner's case that 'transcendent religion' ought to become 'transcendent political power'.

Interwoven with Turner's account of the major religions as affirming some notion of the transcendence is his view that all religions also affirm some account of love for one another. The Christian invocation to 'love your neighbour as yourself', he notes, can be broken down into three questions: Who is my neighbour? Who am I? What is love? All people are my neighbour, responds Turner, and this is a political injunction as well as a moral one, as to act in a loving way I need to understand how my actions (or inactions) affect others, and this requires understanding how society works (p. 19). To put it in terms of the contrast between 'internal' and 'external' morality drawn above, to be able to love we must be able to identify our human potential in its fullest 'external' sense, rather than only imagining the good life in the narrow 'internal' terms constructed by particular social power.

Further, Turner argues that the injunction to 'love my neighbour' is part of the answer to the question 'who am I?' By this he means that being all that I can be as a Christian involves 'loving my neighbour'. Who I am is about how I treat others; my identity is linked to my moral conduct; and being a Christian is linked to good moral conduct, more specifically the practice of loving others. Interestingly, at this point Turner links the loving others to freedom through examining J esus Christ as an example of a religious leader. He states (p. 20):

Through the various specific incidents and parables what shines out is Jesus' freedom - his ability to be open to other people and to react to them and their needs, not in terms of preconceived stereotyped ideas and attitudes, but afresh in each new situation. To be able to love another person is to be able to communicate with her/ him, to be open to her/ his way of seeing the world. It is to go directly to the person, rather than to the role of stereotype. And to be able to do this I must myself be free. I must have escaped from stereotyped attitudes and behaviour patterns imposed by my background and socialisation. This I can only do through self awareness, self-analysis and self-criticism.

So now we have the relationship between the parts better presented. Bring a good Christian (etc), and thus being myself, requires loving others. Loving others requires 
escaping socialised norms which might be oppressive, and this in turn requires self-knowledge of a deep kind that transcends social conventions, which can be gained through religions insight. Indeed, for Turner religion ought to be the source of the transcendent experience which enables us to break the oppressive social imaginary, although 'routinised' religion is not. However, 'transcendent religion enables us to communicate with each other freely and thus love each other as God intended. This enables the conclusion that inspires the title of the book (pp. 20-21).

Already it must be clear how different the Christian human model is from the capitalist model. 'It is easier for a camel to go through the eye of a needle, than for a rich man to enter the Kingdom of Heaven' (Matthew 19, 24-25). If I concentrate on things rather than people I become a slave. I become dependent on things. I behave in a way which the things need me to behave. In each relationship with the other I am not free to be open to another as a person. I have to manipulate the other in such a way as to obtain things from him/ her. And to manipulate the other I have to manipulate myself. This is my essential degradation, for in manipulating myself I finally lose my freedom.

Although not stated clearly and in its entirety in one place, it is possible to reconstruct Turner's argument in the following fashion: (i) transcendent religious experience enables us to (ii) be free from the prejudices of social norms and (iii) to know ourselves and our society and (iv) communicate fully with others to see them and their needs fully, and hence (v) love them more fully as God intends. While not the only possible construction derivable, this is a version reasonably faithful to the text. But even were other versions to be developed, the reality is that Turner's philosophical arguments in Eye of the Needle remain underdeveloped in important ways that leave unclear the precise relationships between transcendent experience, knowledge and love, as well as between freedom, knowledge and communication.

Firstly, is the transcendent experience just the negation of negative social stereotypes and norms through gaining other knowledge, or, as seems to be expressed in the Ndebele quote, is the transcendent some non-cognitive experience which affirms our common identity despite negative social stereotypes, and thus allows us to start reflecting on the implausibility of these stereotypes. That is, do I love because I know better, or do I desire to know better because I am inspired to love? To my mind, the latter seems a more interesting and challenging idea as it allows us to reconnect enough to get rational and democratic debate going again when it has been stopped. Relatedly, is freedom then rooted 'negatively' in the absence of false knowledge, or 'positively' in being empowered to question (and think theoretically) through the epiphany of a shared humanity? Are we freed by enlightenment to find our common humanity, or are we affirmed in our common humanity which enables us to know ourselves and our society, that is, to find enlightenment? Finally, is love enabled by freedom and knowledge, or is love the condition of freedom or knowledge? Must we first be freed from our prejudices and enlightened as to society's ways before we can love each other, or does transcendent assertion of love enable us to know ourselves, each other and society better?

My view is that the most plausible account is that the transcendent experience affirms two values: (i) a common identity as (ii) beings loved by God(s) (which is the key phrase 
missing from Turner's account). To my mind the critical insight revealed by religious transcendence is common human worth which entails both universalising and value-affirming moments. The affirmation of these values through spiritual epiphany then empowers us to: question social norms which undermine this common identity as the worthy subjects of love; know ourselves and others better, love one another, and ourselves, on this basis. As it currently stands Turner's account may be read to suggest that love emerges from better knowledge, but to my mind the approach lacks purchase without a prior commitment to the idea of being worthy in the eyes of God. Without this, we may be empowered to affirm our common identity but in an amoral way, or even as worthless beings. Hence a more plausible account consistent with the very notion of transcendence is that the power of the epiphany lies in the a priori affirmation of common identity and shared worthiness as given by God. From this all else is made possible.

Further, just as religion requires a leap of faith beyond reason, so the transcendent experience cannot be one cashed out in terms of discursive logic, it must be a powerful spiritual insight of identity and love that enables new knowledge and reason. More accurately put, the transcendent religious experience affirms our common human worth before reason. This is of particular practical importance in social contexts where reason appears to have lost its purchase on the public consciousness divided by prejudice and identity politics. Hence the spiritual becomes a practical means through which both to reinvigo- rate critical social norms, and the hope and value of imagining a better political future. Spiritual transcendence is thus one way of repelling the agonies of the TRC or the post-colonial condition. But more on this will follow in the final section.

\section{'Ends not Means' and Participatory Socialism}

Having run the argument that a 'Christian society is one in which we prefer people to things, a society based on freely expressed love (p. 32)', Turner proceeds to show how his vision of participatory socialism based on the principles of maximising human freedom and equality fulfils these values. In justifying this vision he begins from the individual and his or her needs. These he identifies as need to be free from hidden conditioning processes; free to be open to other people; free from external social coercion; and requiring meaningful and creative work that is an expression of autonomous being (ibid). Further, the social system which allows for these must a) enable the individual to have maximum control over their environment, and b) encourage him/ her to interact creatively with other people. For Turner these two ideas are best captured in the idea of 'participatory democracy', and this applies in the workplace and to the representative state.

\section{Participation in the Workplace}

Notably, Turner argues that the work place must also be democratised as this is central to forms of power experienced by most of us. In this way he begins to mark out quite a distinct vision of socialism from the highly centralised, bureaucratic, state socialism of the former eastern bloc. He argues that the two hierarchies that currently characterise 
production, control and knowledge, can be reformed such that power is decentralised to regular meetings of all workers and an elected worker's council with term limits. He makes a conscious effort to balance institutional knowledge against the tendency to develop and abuse bureaucratic power (pp. 33-34).

Arguing that the enterprise is also a socialisation process (what we might term a 'school for democracy') and not only a work-place, Turner holds that meaningful participation in the workplace develops the qualities essential to the appropriate model of human being: autonomy, initiative and self-confidence. Notably, this 'lays the basis for love as a constant rather than as a fleeting relationship between people' (p. 36). Drawing on real world studies, he makes the case for various reforms to prevent oligarchical tendencies, including the idea of 'back to the shop floor' for managers. Acknowledging the costs to efficiency measured in terms of price, that such institutions would incur, Turner points out that 'in our Christian model' the enterprise is not only intended to produce goods, but also to be enabling environment for people to become more educated and autonomous ( $p$. 42). He generally downplays the role of leadership in these contexts, which to my mind is problematic, especially for a country like South Africa which finds itself in a transition from old to new social and political institutions and which may require a special kind of leadership to affirm the move to the transcendent rather just mobilise existing prejudices.

\section{Participation in a Decentralised Representative State}

Turner then moves to examine political institutions. Moving from a commitment to freedom as the basis of the ideal society, he argues that we need the state to co-ordinate those of our actions which affect others so as to maximise freedom in our private lives (p. 45). He argues for a central state to co-ordinate the worker's enterprises amongst other things - arguing against the justifications of associa- tional democracy (see Hayek 1960 and Friedman 1962) on the basis of the dominance of money as a source of power, and its access to organisation and information. He does allow for the possibility that capitalists can be voted out of power, but still maintains that 'the illusion of pluralism' does not challenge the fundamental power structure (p. 47). He embraces a central planning approach overtly against a free-market economy of worker-controlled enterprises (p. 50), but does affirm some role for a market mechanisms, financial instruments, information distribution and 'pure imperative planning'. He acknowledges that he does not explain how this mix ought to be affected, leaving open a range of options.

More importantly he argues that the need for planning raises the problem of who shall plan, and the concomitant dangers of (i) the centralisation of power, and the addiction to status many leaders develop, as well as (ii) the isolation of leadership from the daily life of most ordinary folk (p. 54). The solutions to these problems are to:

a) make the decision hierarchies as short as possible through greatest possible decentralisation

b) make the conditions of life of the decision-makers the same as the people, and 
c) provide the greatest knowledge possible on the part of the people of the problems of government

He sees worker-controlled enterprises with a significant degree of autonomy as the central mechanisms to achieve these goals (pp. 556), but makes no mention of electing the central planners - although in the final chapter he does write that 'universal suffrage is a prerequisite for a just society' (p. 68), adding that the political system will be based on universal franchise and maximum decentralisation, with real powers for provincial and local government (p. 73). At each level there will be a close relationship between bodies elected on a normal constituency basis and those elected on an enterprise basis. He goes so far as to advocate the pooling of resources and the development of an attitude of 'respect for the common material world which is the basis of my relations with others', arguing that the latter attitude is 'obviously closer to the Christian ideal' (p. 57). Notably he criticises the Soviet Union for failing to empower ordinary people, and instead creating 'a large, inefficient and undemocratic state bureaucracy'.

The case for 'participatory democracy' is buttressed by appeal to social psychological literature on education which shows that 'the development of self-discipline and the development of intelligence are linked, and that both involve the capacity to see things from man points of view' (p. 64). This, argues Turner, shows how the development of these capacities are inhibited by forms of control that depend mostly on authority and obedience. Indeed, Turner follows Illich in suggesting that workplaces could also be learning environments for children as observers or participants (pp. 64-5).

Applying his theory to South Africa in the 1970s, Turner holds that apartheid South Africa is based on a model incompatible with Christianity, and so a fundamental redistribution of power and money is required. Universal suffrage is a prerequisite for both political justice and stability, but not a sufficient condition (p. 69). For stability we also need no sharp division into groups with contradictory interests, which he argues is primarily due to the unequal distribution of wealth. This is overlain by race, notes Turner, but prejudice can be cured by education, whereas conflict of interests cannot. In short, the wealth gap needs to be done away with. Further, citizens must be adequately integrated into the political system. Voting every five years is not enough for political parties can become oligarchies, and this leads to the atomisation of the mass society, with frequent contact but no organised relationship around a common goal. Hence, we will find expressions of alienation in such a society (p. 71):

Materially and psychologically frustrated, wanting to belong with other people but continually being forced apart from them again, their only social action is likely to be in sudden and irrational acts which provide a release for their frustration, and the satisfaction of at least temporary total identification with the crowd: rioting, lunch-gangs and similar 'mob actions' are characteristic of the mass society. The alternative to mob action is the apathy of total withdrawal into self, an apathy, which being based on social frustrations, is inherently unstable and can turn back into mass violence. 
On the basis of these remarkably prescient predictions given the growing levels of localised popular protest around South Africa in the last five years, Turner argues that South Africa needs a different kind of system, one based on a rich range of intermediary organisations between the individual and the government. Hence representative democracy is supplemented both with decentralisation and with the creation of worker-controlled enterprises run along participatory lines (p. 73). The lack of such structures, he notes, is typically the case in Africa with nothing to mediate old tribal structures and the new central government. Politics retreats to the city, but reduces to a struggle amongst elites for the spoils of office with no mass involvement (pp. 71-2). In this regard he sees the mass party and formal structures as the solution, making positive reference to Ujamaa in Tanzania. Notably though, he makes no reference to civil society or Churches as social actors, but he does identify the normative potential of the Church to change white South Africans: 'If the Christian churches can rediscover their transcendence and show the meaning of love to white South Africans then a peaceful resolution of the struggle will be possible' (p. 81).

\section{Turner and a Post-Apartheid Politics of Hope}

In some ways Turner's vision on Eye of the Needle is not very conducive to the case for faith-based organisation political advocacy. For instance, Turner does not identify any explicit social or political role for Churches in his post-apartheid participatory socialist state. Indeed, it may be argued ${ }^{2}$ that while Turner, unlike Marx, sees clearly how religion is vital for politics and society in general, he does not see the transcendent role of religion as likely to occur within localized and often issue-specific organizations, but in its potential to provide completely alternative ways of associating with other humans, and thus as an all-transforming, revolutionary and liberatory force.

Thus, it could be argued, Turner reflects the influence of both Rousseau and Kant in seeing religion as serving a crucial 'civil' function, following Rousseau, and also embracing the notion it can somehow stand outside of 'civil society' and act as a form of transcendental critique, following Kant. Notably, neither account seems to rest on or give rise to an argument that actually existing faith-based organizations can perform this function. The notion that these sort of organizations, or in modern parlance 'civil society organizations', could perform these roles is anathema to both thinkers, and thus presumably to Turner too.

That there is something to this view is confirmed in Turner's conception of political power as centred on the institutions of the market and the state. Further, he is generally dismissive of the view that civil society constitutes a meaningful counter weight to formal power. However, for two reasons this insight need not derail the idea that faith-based organisations could play a role in advocating for a progressive politics on transcendent grounds. The first and most obvious reason is that this is precisely what Turner is doing in The Eye of the Needle. The book was written as part of an anti-apartheid project conducted by the South African Council of Churches, and is thus a clear example of the kind of religiously redeemed and yet progressive advocacy by faith-based organisations that this 
paper defends. It seems unlikely to me that Turner would be unaware of the disjuncture between his theory and his activism, but if so, then he stands accused of some kind of performative contradiction.

The second and more important reason is that, as argued below, it is possible to embrace Turner's insights into the important political implications of a religious epiphany which affirms our common human worth without embracing his subsequent arguments on political ethics or his model of an ideal society. Indeed, this is precisely what I set out to do below, indicating my preferences for a different ethics and model, and one which includes a role for civil society in social power-relations, and more specifically, a role for faith-based organisations in progressive political advocacy. Hence Turner's scepticism towards faith-based organisations and civil society more generally, rooted in his intellectual history in Rousseau, Kant and Marx, is no obstacle to my general case.

There are at least two ways in which Turners arguments could be marshalled behind the case for faith-based citizenship advocacy today. The first is to acknowledge that 'the struggle is not over', and hence that religion has a role in realising a society based on the religious epiphany of transcendent love. The second, and more important, is to show how the transcendent religious experience affirms the core values of our common human worth, and that from these values we can justify a social ethics like autonomy as the basis for a legitimate political system. Further, just as there is a distinction between religious insight and normative political philosophy, so the affirmation of an ethic like autonomy enables a range of political models or visions other than just participatory socialism. Last, and far from least, the transcendental experience promises to affirm both the key values and the virtues of normative imagining (his 'theoretical attitude'), normally redeemed through some progressive discursive logic, but in a context where the latter struggles to get real traction. He shows how, in hard times, religious transcendence can give us grounds for political hope.

\section{Option One: Religious Organisations and Socialism}

The first move is the more obvious, as it is clear that post-apartheid South Africa is not the participatory socialist state that Turner envisaged. While it is an electoral democracy based on universal franchise, and there are some real powers enjoyed by provincial and local spheres of government (that is, some decentralisation), contemporary South Africa is clearly not a socialist state. In addition to being mostly a capitalist system, South Africa also has an active civil society and a form of education based on authority and obedience. Relating this reality to Turner's views in the Eye of the Needle, it is straightforward to argue that he would hold that South Africa's transformation is far from over, as people are treated as means to money and power only rather than as ends in themselves.

Given that the authority systems and economic exploitation of liberal-capitalism are incompatible with the values identified by transcendental religion, Turner would hold that the struggle for human liberation has yet to end. Further, given that he sees a role for organised religion in opposing apartheid, as revealed by his own practice, it follows that he ought to see a role for 'transformative' religion in opposing the new order too. More specifically, 'transformative' religion has a special ideological role to play in the ongoing 
struggle for common human worth, and is thus a major source of the alternative discourse with which to empower the critique electorally-legitimised capitalism. Further, through their power to transform popular consciousness in a more human-centred direction, progressive faith- based organisations can enhance the chances of a peaceful resolution to class related conflict.

\section{Option Two: Religion, Autonomy and Inspiration}

The second move is less obvious, but I would argue, much more interesting and powerful, and centres on the idea that spiritual transcendence can reinvigorate both the particular values of common human worth and the virtue of normative imagining in a context where conventional progressive politics is struggling to make itself heard above the clamours of prejudice and populist demagoguery. While Turner's account of participatory socialism is remarkable for its time, ${ }^{3}$ it is not the only model of social and political utopia enabled by the religious epiphany of a common identity and worthiness. Notably the structure of Turner's argument is threefold: (i) religious epiphany which affirms our common identity and worth, and which implies (ii) a society based on the ethic of treating people as ends in themselves, and (iii) participatory socialism as the model most appropriate to this ethic. My argument is that the links between each of the three steps in the argument is somewhat looser than Turner suggests, and that one can affirm the utility of the idea of religiously redeemed values of common human worth without embracing precisely the same social ethic, and certainly without embracing participatory socialism.

The first case to make is that participatory socialism is not the only theoretical model consistent with a Kantian moral ethic. As entire careers and literatures have been built around this point I shall not belabour it, but rather refer to the fact that varieties of Marxism, social democracy, left liberalism, anarchism and democratic theories all make similar appeals. Some examples would include the Frankfurt School's long-standing concerns with the effects of domination and technological rationality on individual autonomy, Kymlicka's 'liberal nationalist' concern of redeeming individual agency through appropriate forms of cultural recognition, Held's cosmopolitan social democracy, and the capability approach to development articulated by Amartya Sen and Martha Nussbaum.

Of course the fact that a great diversity of social models are compatible with some account of autonomy or 'positive liberty' does not, of itself, make Turner's argument for participatory socialism wrong, but it does imply that one can embrace both steps one and two of his argument without embracing his third. This opens the door for marrying aspects of Turner's argument into the political theologies of the major South African religions without committing them to participatory socialism, as well as into arguments for the relevance of religion to new forms of political imagining in the current post-apartheid condition. 
The second move is to loosen the connection between transcendent religious insight into our common human worth and Turner's account of treating people as ends in themselves. Notably this ethical view bears a close resemblance to Immanuel Kant's (1981) ethical theory, specifically this second formulation of the categorical imperative which states:

Act in such a way that you treat humanity, whether in your own person or in the person of any other, always at the same time as an end and never merely as a means to an end.

Again the reason for wanting to loosen the link with Kantian ethics is that there are other ethical theories consistent with the transcendent affirmation of our common human worth, and frankly I prefer some other version of autonomy or positive freedom. Be this as it may, the complex relationship between means and ends identified by Turner finds ambivalent expression in his discussion of the difference between transcendent and routinised religion. Where religion in the transcendent mode is liberatory and transforms social power, in the routinised mode it usually conserves the social order.

Notably this 'transcendent'/'routinised' distinction appears to track Weber's distinction between charismatic and routinised authority. Charismatic authority is 'power legitimized on the basis of a leader's exceptional personal qualities or the demonstration of extraordinary insight and accomplishment, which inspire loyalty and obedience from followers' (Weber 1964: 117). This is power that centres almost entirely on a leader, and tends to challenge the status quo. There are clear and strong parallels here between Weber's account of charismatic authority and Turner's account of 'transcendental' religion. The latter occupies the same revolutionary role as disrupting the social order in the name of a fundamental insight into the human condition. As we have seen, it is this conception of religious experience and, critically, religious organisation that Turner affirms against 'routine' religion.

But if Turner is implicitly or even explicitly using Weber's distinction he opens himself up to the problem of the sustainability of charismatic organisation. Hence Weber argues that once the charismatic leader goes, the organisation that has been founded will inevitably be succeeded by a bureaucracy which is organised along rational, or traditional-rational, lines. In short, charismatic authority is always short-lived and eventually becomes routinised into 'rational' or 'traditional-rational' forms. Thus Turner needs an intervening step in the argument between transcendence insight and social models, which Turner identifies as the social principle of 'preferring people to things', or treating people as 'ends in themselves rather than people' (p. 21).

Given the modernity is often described as the rise of organisation (Giddens) or knowledge-systems (Habermas) it seems being treated as things is endemic to modern life and, as noted above, it is hard to see how it could be otherwise. Indeed, it seems to me that what matters more is not so much that we are treated as things, but if we are only treated as things - as Kant points out. To the extent we are able to participate in the formulation of the ends to which rational administration is intended on an ongoing basis, we can be said 
to reclaim some power over our lives and redeem the recognition of our basic worth and, under the right conditions, our equality. This crude formulation reflects much of contemporary democratic social theory, for example, the Habermasian affirmation of 'communicative reason' as primary over instrumental reason.

Lastly and perhaps most importantly, Turner's views redeem the point of utopian thinking in a dystopian context. His insights as regards the religious grounds for our common human worth provide us with both content and methodology to revive a progressive politics of hope in our (perhaps gloomy) post-colonial condition where calm and rational debate is often outweighed by purple invective. In respect of content, our common human worth is redeemed in religious fashion through pointing to our common identity and worth by being love by God, so enabling a discursive rationality that otherwise enjoys comparatively limited purchase in our context of personality-based politics. This offers a resource to repel advocates of identity-based negativity, whether racial, religious, ethnic or national in the name of human rights and dignity. It provides a shade from the vindictive politics of zero-sum factionalism; relief from the fetishisation of fame and a buoyant alternative to the relentless consumerist gorging. It is like Nelson Mandela to Robert Mugabe, Bishop Tutu to Ray McCauley and the Mother Teresa to Paris Hilton. In sum, it affirms the fact that God, and not just reason, makes us equal and makes us worthy of love.

Further, in pointing to the power of the transcendent act to reaffirm our common human worthiness, Tutu's moment of prayer for example, Turner reaffirms the importance of the act of faith, of believing, of hoping and of imagining to realising a better future. The transcendental religious experience thus redeems not just key values, but also the act of normative thinking and utopian imagining, of adopting the theoretical attitude. In hard times, religion can affirm both progressive values and normative imagining in ways beyond discursive reason.

\section{Conclusion}

At the heart of the argument in this paper is the idea that transcendent religion offers a way back to affirming the values of common human worthiness, and the act of imagining a better society on these grounds, in a particular time and place when such things are not easily available through discursive reason. More specifically the arguments of Richard Turner in the Eye of the Needle show how the religious notions of transcendence and love provide some basis for reclaiming progressive political norms, and also affirm the possibility and importance of imagining a better future for all. This is in addition to the more obvious insight that faith-based organisations have a practical role to play in realising a society which puts people first. Turner shows how, when appeal to reason alone fails, religious transcendence can inspire political hope.

Of course there are many ways in which one could disagree with Turner. Even desiring the same political outcomes and also starting from religion, one could chart a different argumentative path. The point is not so much that Turner is right but that he is one the 
few South African political thinkers to take seriously the implications of religion for politics. Further, he offers a substantial and sophisticated account of how to redeem the progressive project starting from spiritual grounds. Indeed, seen in pragmatic political terms, this approach may have as much, if not more, relevance in the 'post-colonial condition' of contemporary South Africa than in the era of grand apartheid when Turner wrote Eye of The Needle. This fact in itself offers us reason to take normative imagining seriously, and it also offers us reason to hope.

LAURenCe PIPER is Professor and Head of Department in Political Science at the University of the Western Cape. A graduate of Cambridge University, an early interest in Zulu nationalism in the transition to democracy in South Africa has given way to research into new practices and institutions of democracy, both comparatively in the developing South and in empirical and normative theory.

\section{Notes}

1. The title page of the Eye of the Needle lists Sprocas as the 'Special Programme for Christian Action in Society'. The South African Council of Churches website, and the South African History Online website list it as 'Study Project on Christianity in an Apartheid Society'.

2. My thanks to an anonymous reviewer for drawing this point to my attention.

3. He is well ahead of the global left in his critique of Society Style state socialism, and his argument for worker-run enterprises anticipate work by the 'analytical Marxists' of the late 1970s and 1980s. Indeed his work on participation, while underdeveloped as regards political institutions, anticipates emergent thinking in politics and development studies around deepening democracy through implementing new, localised, participatory institutions which supplement representative structures (Gaventa 2006).

\section{References}

De Kadt, Raphael. 2010. Professor of Political Studies, St Augustine's College of South Africa. Personal communication, 05 March 2010.

Friedman, Milton. 1962. Capitalism and Freedom. Chicago: University of Chicago Press.

Gaventa, J ohn. 2006. 'Triumph, Deficit or Contestation: Deepening the Deepening Democracy Debate', IDS Working Paper 264.

Giddens, Anthony. 1991. Modernity and Self-Identity. Cambridge: Polity.

Habermas, Jurgen. 1984. The Theory of Communicative Action, Vol. 1: Reason and the Rationalization of Society. Boston, MA: Beacon Press.

Hayek, Friedrich. 1960. The Constitution of Liberty. Chicago: University of Chicago Press. Kant, Immanuel. 1981. The Grounding for the Metaphysics of Morals. Indianapolis: Hackett Publishing Company. 
Ndebele, Njabulo S. 2007. 'Moral Anchor: An Interview with the Arch (1998)', in Fine Lines from the Box: Further Thoughts about Our Country. Johannesburg: Umuzi/ Random House, 77-83.

Laurence Piper. 2009. 'Faith-Based Organisations, Local Governance and Citizenship in South Africa', in Duncan Brown (ed). Religion and Spirituality in the Post-Colonial Condition. Pietermaritzburg: University of KwaZulu-Natal Press, 54-77. ISBN: 9781 869141677.

Rousseau, J ean-J acques. 1987. The Basic Political Writings. Indianapolis: Hackett Publishing Company.

Turner, Richard. 1972. The Eye of the Needle. J ohannesburg: Spro-cas. Weber, Max. 1964. Theory of Social and Economic Organization. New York: Free Press. 